\title{
Optimalisasi Program Reformasi Birokrasi Perguruan Tinggi Menggunakan AHP dan BSC
}

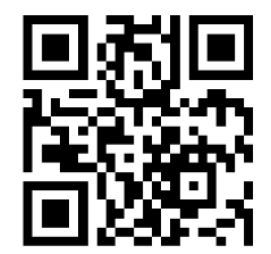

\author{
Khresna Bayu Sangka ${ }^{1}$, Agung Nur Probohudono를 Okta Hadi Nurcahyono ${ }^{3}$ \\ DOI: https://doi.org/10.36339/jaspt.v4i2.365
}

\begin{abstract}
Abstrak
Penerapan reformasi birokrasi merupakan salah satu cara preventif yang efektif untuk menekan perilaku korupsi di Indonesia. Reformasi adalah proses untuk mengubah proses, prosedur birokrasi publik dan sikap serta perilaku birokrat untuk mencapai efektivitas birokrasi dan tujuan pembangunan nasional. Reformasi kegiatan sebagai padanan lain dari perubahan, perbaikan dan modernisasi. Ruang lingkup reformasi tidak hanya terbatas pada proses dan prosedur, tetapi juga mengaitkan perubahan pada tingkat struktural dan sikap terhadap perilaku dan budaya sehingga arah reformasi yaitu pencapaian pelayanan publik dapat dicapai secara efektif dan efisien.Studi komprehensif telah dilakukan yang dapat menghasilkan model penilaian yang sesuai dengan arah dan tujuan reformasi tersebut. Kombinasi pendekatan balanced scorecard (BSC) dan analitik hierarki proses (AHP) diyakini dapat mengidentifikasi, mengukur, dan menghilangkan perbedaan persepsi yang dapat mengoptimalkan kinerja organisasi. Lebih dalam lagi, model tersebut diterapkan di semua organisasi pelaksana reformasi birokrasi. Studi ini menemukan bahwa empat perspektif Balanced Scorecard yang digunakan memiliki perbedaan bobot dan prioritas karena banyaknya perbedaan tingkat subkategorinya. Padahal tidak ada penilaian yang sempurna. BSC yang dikombinasikan dengan AHP saat ini, dapat digunakan untuk membuat metode penilaian terbaik yang mudah digunakan untuk menilai kinerja organisasi.
\end{abstract}

Kata Kunci: balanced scorecard, proses hierarki analitik, reformasi birokrasi.

\section{PENDAHULUAN}

Program reformasi birokrasi Universitas Sebelas Maret (UNS) mengacu pada program reformasi birokrasi Kementerian Riset, Teknologi, dan Pendidikan Tinggi serta mengacu pada Perpres Nomor 81 Tahun 2010 tentang Grand Design Reformasi Birokrasi 20102025 dan Perpres. Menteri Pendayagunaan Aparatur Negara dan Reformasi Birokrasi Nomor 11 Tahun 2015 tentang Road Map Reformasi Birokrasi 2015-2019. Program reformasi birokrasi UNS merupakan program yang terlembaga, berkelanjutan, dan diharapkan terus berjalan tanpa kehilangan momentum reformasi. Tujuan dari program reformasi birokrasi UNS adalah untuk mewujudkan birokrasi yang responsif, bertanggung jawab, akuntabel, transparan, efektif, efisien, bersih dan berkualitas serta

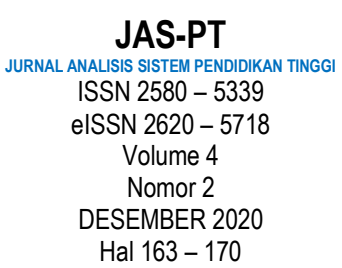

FORUM DOSEN INDONESIA 
menjunjung tinggi nilai keadilan tanpa diskriminasi dan nilai profesional. Penerapan nilainilai reformasi birokrasi harus sejalan dengan prinsip antikorupsi untuk menanamkan jiwa integritas.

Penelitian ini bertujuan untuk menganalisis, merancang dan mengembangkan model asesmen yang sesuai untuk mengukur perbedaan kinerja organisasi setelah dan sebelum pelaksanaan reformasi birokrasi, dalam kerangka balanced scorecard dengan pendekatan proses hierarki analitik. Selanjutnya, model tersebut diterapkan di semua organisasi pelaksana reformasi birokrasi. secara mendalam terkait pelaksanaan pendidikan antikorupsi dalam pelaksanaan reformasi birokrasi. Untuk mengetahui sejauh mana metode ini dilakukan dengan membuat kerangka konseptual dan instrumen pengukuran terkait dengan metode pembelajaran dan pendekatan yang diambil dalam pelaksanaan reformasi birokrasi.

Christensen dan Eyring (2011) dalam penelitiannya menjelaskan bahwa perguruan tinggi saat ini harus mengubah cara berpikirnya untuk meninggalkan tradisi lama dalam perkembangan teknologi dan sains. Saat ini perguruan tinggi harus lebih fokus dan berorientasi pada hasil iptek yang berkinerja tinggi. Menurut Christensen dan Eyring (2011) hal ini terjadi karena universitas berada pada era manajemen baru. Era ini diharapkan berdampak baik bagi pengelolaan perguruan tinggi. Jika sebuah universitas menerapkan hal tersebut, maka universitas memiliki nilai lebih untuk meningkatkan nilai prestisenya di mata pengguna jasa universitas.

Penelitian dari (Brennan et al., 2008) memberikan bukti empiris bahwa inovasi di perguruan tinggi dipengaruhi oleh faktor kelembagaan baik di dalam perguruan tinggi maupun pemangku kepentingan di luar perguruan tinggi. Sistem kelembagaan ini mempengaruhi munculnya inisiatif inovasi, pengembangan kelembagaan, transfer invensi dan teknologi yang dihasilkan, dan hasil universitas. Pentingnya lembagalembaga ini mendorong penerapan universitas korporasi yang baik di universitas.

Saat ini semua organisasi di Indonesia dituntut untuk menerapkan tata kelola yang baik (Good Governance). Universitas tidak terkecuali. Perguruan tinggi wajib melaksanakan tata kelola yang baik. Tata kelola yang baik dalam Universitas dapat dilakukan dengan memanfaatkan "Triple Helix" (e Silva et al., 2012). Tata kelola "Triple Helix" merupakan gabungan dari tiga pihak yaitu Universitas, Perusahaan dan Pemerintah. la berharap dengan penerapan tata kelola "Triple Helix" ini akan terjalin kesinambungan yang baik antara perguruan tinggi, perusahaan, dan pemerintah. Tidak hanya itu, menurut North (1990), penerapan manajemen universitas yang baik dapat meningkatkan kinerja perekonomian.

Speer (2012) menyatakan bahwa good governance harus diikuti dengan kebijakan partisipatif. Kebijakan partisipatif akan meningkatkan respon pemerintah, meningkatkan pelayanan publik, dan meningkatkan kontribusi dalam bentuk kesejahteraan. Dengan kebijakan partisipatif diharapkan akan terjalin hubungan timbal balik antar pemangku kepentingan yang terlibat (Zahreawati, 2011).

Perguruan tinggi merupakan salah satu "sektor publik" yang mempunyai tugas untuk mengabdi kepada masyarakat dalam bidang pendidikan. Menurut Beverungen,

JAS-PT

JURNAL ANALISIS SISTEM PENDIDIKAN TINGG

ISSN $2580-5339$

eISSN $2620-5718$

Volume 4

Nomor 2

DESEMBER 2020

Hal 163 - 170 Hoedemaekers, dan Veldman (2014), perguruan tinggi hendaknya tidak berasumsi bahwa perguruan tinggi adalah perusahaan swasta yang mempunyai tujuan laba atau "profit oriented". Pola pikir ini harus tertanam di setiap pemangku kepentingan universitas. Perguruan tinggi sebagai bagian dari "sektor publik" juga dituntut untuk melakukan reformasi birokrasi.

FORUM DOSEN INDONESIA 
Reformasi birokrasi merupakan salah satu bentuk good governance. Andrews (2015) reformasi sektor publik muncul sebagai pendukung pembangunan bangsa. Sebelum era reformasi, tepatnya tahun 1998, pemerintah dikritik karena perilaku korupnya. Dengan reformasi birokrasi diharapkan pemerintah mampu menopang dirinya ke arah yang lebih baik dan mampu menghindari perilaku korupsi.

Wallis dan Dollery (2001) menyatakan bahwa reformasi birokrasi harus didukung oleh kemauan dan niat yang kuat dari pimpinan organisasi. Wallis dan Dollery (2001) juga menyatakan bahwa jika pimpinan organisasi sudah memiliki kemauan dan niat, maka jajaran dibawahnya akan mengikuti.

Wihantoro dkk. (2015) menyatakan bahwa reformasi birokrasi sangat dipengaruhi oleh budaya organisasi. Pendapat dari Wihantoro et al. (2015) juga mengkonfirmasi pendapat Efferin dan Hopper (2007). Efferin dan Hopper (2007) mengungkapkan bahwa kebudayaan di Indonesia sedikit banyak telah mempengaruhi penguasaan nasional. Dalam makalahnya Wihantoro et al. (2015) menyatakan bahwa reformasi birokrasi sangat dibutuhkan oleh bangsa Indonesia karena reformasi birokrasi mendukung pembangunan nasional.

Balanced Scorecard (Kaplan dan Norton 2000) adalah alat analisis pengukuran kinerja yang mampu menerjemahkan misi dan strategi ke dalam berbagai tujuan dan ukuran, yang disusun dalam 4 perspektif: keuangan, pelanggan, proses bisnis internal, serta pertumbuhan dan pembelajaran. Kartu skor memberikan kerangka kerja, bahasa, untuk mengkomunikasikan misi dan strategi dan menggunakan pengukuran untuk menginformasikan pekerja tentang faktor-faktor yang mendorong kesuksesan saat ini dan masa depan. Kerangka Balanced Scorecard tidak hanya terbatas pada organisasi bisnis, tetapi organisasi publik juga dapat menggunakannya dengan landasan yang berbeda. Jika dalam organisasi bisnis fokusnya adalah pada perspektif keuangan, maka dalam organisasi sektor publik fokusnya adalah pada perspektif pelanggan (Kaplan dan Norton, 2000). Tujuan utama organisasi publik bukanlah maksimalisasi hasil keuangan, tetapi keseimbangan akuntabilitas keuangan (anggaran) melalui pelayanan kepada pihak yang berkepentingan (stakeholders) sesuai dengan visi dan misi organisasi pemerintah dengan pertimbangan yang cenderung diutamakan oleh organisasi pemerintah. kualitas "layanan publik" (Gasperz 2006).

Penetapan tujuan pada setiap perspektif Balanced scorecard mengacu pada Rencana Strategis, sehingga setiap sasaran yang ada dalam Renstra dapat dipetakan secara tepat ke dalam kerangka kerja Balanced scorecard, sehingga perlu dipahami terlebih dahulu hubungan keduanya. Konsep desain pemetaan rencana strategis ke dalam model Balanced Scorecard secara lengkap terdapat pada Tabel 1.

Analytic Hierarchy Process (AHP) Merupakan metode untuk menyelesaikan suatu keadaan tidak terstruktur yang kompleks menjadi beberapa komponen dalam susunan hirarkis, dengan memberikan nilai subjektif tentang kepentingan relatif masing-masing variabel, dan menentukan variabel mana yang memiliki prioritas tertinggi untuk mempengaruhi hasil akhir suatu variabel. situasi itu (Saaty dan Vargas, 2012). Proses pengambilan keputusan pada dasarnya adalah memilih alternatif terbaik. Seperti penataan masalah, menentukan alternatif, menentukan nilai probabilitas untuk semua variabel wajib, menentukan nilai, persyaratan preferensi waktu, dan spesifikasi risiko (Turban, 2005).

Terlepas dari lebar alternatif yang dapat ditentukan atau penilaian rinci nilai probabilitas, batasan yang tetap menyebar adalah dasar untuk perbandingan dalam bentuk kriteria tunggal. Dengan hierarki, suatu masalah yang kompleks dan tidak terstruktur diselesaikan ke dalam kelompok-kelompok dan disusun menjadi bentuk hierarki.

JAS-PT

JURNAL ANALISIS SISTEM PENDIDIKAN TINGGI ISSN $2580-5339$ elSSN $2620-5718$ Volume 4 Nomor 2 DESEMBER 2020 Hal 163 - 170

FORUM DOSEN INDONESIA 
Tabel 1. Pengukuran Strategis Balanced Scorecard

\begin{tabular}{|c|c|c|c|}
\hline PERSPEKTIF & TUJUAN & PENGUKURAN & SUMBER DATA \\
\hline \multirow{26}{*}{ KONSUMEN } & Nilai Program Studi & Rangking Eksternal (Akreditasi Prodi) & dikti \\
\hline & Siswa/Orang Tua & Evaluasi Layanan Mahasiswa & remun \\
\hline & Kualitas Akdemik & Evaluasi Kepuasan Mahasiswa & siakad \\
\hline & Kualitas Instruksi & Evaluasi Alumni & cdc \\
\hline & \multirow[t]{6}{*}{ Penempatan Siswa } & Evaluasi Lulusan & cdc \\
\hline & & Evaluasi Akreditasi & dikti \\
\hline & & Evaluasi Perekrutan (Keketatan, Skor Masuk) & cdc \\
\hline & & Waktu Tunggu Kerja & cdc \\
\hline & & Rata-Rata Gaji Pertama & cdc \\
\hline & & Jumlah Perusahaan yang melakukan Rekruitmen di Kampus & cdc \\
\hline & Staf Fakultas & Kepuasan Staff & NA \\
\hline & Kesempatan Pertumbuhan & Pertumbuhan Gaji/Insentif & Keuangan, Remun \\
\hline & \multirow[t]{4}{*}{ Kesempatan Pembelajaran } & Kelulusan Studi Lanjut & Kepegawaian \\
\hline & & Kelulusan Pelatihan Sertifikasi & Kepegawaian \\
\hline & & Peran sebagai pembicara di luar institusi & P4M \\
\hline & & Kesejahteraan Staff & \\
\hline & Alumni & Feedback Alumni & \\
\hline & Update Pengetahuan & Survey Kepuasan Alumni & \\
\hline & Penguatan Pengetahuan & Jumlah Lulusan yang direkrut & \\
\hline & \multirow[t]{2}{*}{ Rekruitmen Perusahan } & Jumlah Pekerjaan yang ditawarkan per mahasiswa & \\
\hline & & Jumlah Gaji yang ditawarkan & \\
\hline & \multirow{2}{*}{$\begin{array}{l}\text { Perluasan Pengetahuan: } \\
\text { Penelitian, Konsultan, }\end{array}$} & \multicolumn{2}{|c|}{ Jumlah orang yang mendapatkan manfaat dari program training yang dilakukan institus } \\
\hline & & Grant yang didapatkan dari industri & \\
\hline & \multirow[t]{3}{*}{ Masyarakat } & Jumlah alumni di Sektor Publik dan Layanan Publik & \\
\hline & & Catatan filantropi alumni, fakultas, staf & \\
\hline & & Rekaman alumni, fakultas, staf yang bersih secara hukum & \\
\hline \multirow{9}{*}{$\begin{array}{l}\text { PROSES } \\
\text { BISNIS } \\
\text { INTERNAL }\end{array}$} & Continuos Improvement & & \\
\hline & \multirow[t]{2}{*}{ Jaminan Mutu } & Distribusi Penerimaan Penghargaan & \\
\hline & & Evaluasi Kompetensi Mahasiswa & \\
\hline & \multirow[t]{2}{*}{ Program Internship } & \multicolumn{2}{|l|}{ Jumlah Internship yang tersedia, jumlah perusahaan yang tersedia } \\
\hline & & evaluasi mahasiswa & \\
\hline & Efisiensi Biaya & Rasio Fakultas - Siswa & \\
\hline & & Biaya Studi Mahasiswa & \\
\hline & Kurikulum yang spesial/unik & Jumlah fakultas dengan area spesialis & \\
\hline & & Jumlah program spesial & \\
\hline \multirow{15}{*}{$\begin{array}{l}\text { KAPASITAS } \\
\text { ORGANISASI }\end{array}$} & \multirow{3}{*}{$\begin{array}{l}\text { Pertumbuhan Profersional } \\
\text { Fakultas }\end{array}$} & Jumlah Presentasi pada Konferens & \\
\hline & & Jumlah Seminar yang diikuti & \\
\hline & & Biaya Perjalanan Keikutsertaan Konference & \\
\hline & \multirow{3}{*}{$\begin{array}{l}\text { Motivasi dan Pengembangan } \\
\text { Staff }\end{array}$} & Presentase anggaran untuk mengembangan staff & \\
\hline & & Indeks Kepuasan Staff & \\
\hline & & Jumlah Multiskilled staff & \\
\hline & \multirow{3}{*}{$\begin{array}{l}\text { Penggunana Teknologi dan } \\
\text { Inovasi Pembelajaran }\end{array}$} & Jumlah Matakuliah yang berhubungan dengan teknologi baru & \\
\hline & & Jumlah Wokshop pembelajaran yang diikuti staff & \\
\hline & & Jumlah Hibah Inovasi Pembelajaran & \\
\hline & \multirow[t]{2}{*}{ Inovasi Kurikulum } & Revisi kurikulum dalam jangka waktu 5 tahun & \\
\hline & & Jumlah Matakuliah Baru yang ditawarkan dalam 5 tahun & \\
\hline & \multirow{2}{*}{$\begin{array}{l}\text { Kerjasama rekruitmen dengan } \\
\text { perusahaan }\end{array}$} & jumlah perusahaan yang terlibat & \\
\hline & & jumlah aktivitas kerjasama & \\
\hline & \multirow[t]{2}{*}{ Pengelolaan } & Produktivitas Riset & \\
\hline & & Jumlah inisiasi kewirausahaan & \\
\hline \multirow{6}{*}{ FINANSIAL } & Pendapatan & Jumlah Grant yang didapatkan & \\
\hline & & Trend Pendaftaran & \\
\hline & & Peningkatan Input Siswa & \\
\hline & Efisiensi & Efisiensi Penggunaan Fasilitas & \\
\hline & & Pembiayaan Per Mahasiswa & \\
\hline & & Statistik penggunaan Fasilitas & \\
\hline
\end{tabular}

\section{Sumber: Data Sekunder Diolah}

\section{A.Keuntungan dari Analytical Hierarchy Process (AHP)}

Struktur hierarki sebagai konsekuensi dari kriteria yang dipilih hingga subkriteria yang paling memperhitungkan validitas hingga toleransi terhadap inkonsistensi berbagai

\section{JAS-PT}

JURNAL ANAUSIS SISTEM PENDIDIKAN TINGG ISSN $2580-5339$ eISSN $2620-5718$

Volume 4

Nomor 2 DESEMBER 2020

Hal 163 - 170 kriteria dan alternatif yang dipilih oleh pengambil keputusan, dengan mempertimbangkan ketahanan atau ketahanan sensitivitas keluaran analisis pengambil keputusan (Saaty dan Vargas, 2012). Selain itu, AHP memiliki kemampuan untuk menyelesaikan masalah multi objektif dan multi kriteria berdasarkan perbandingan preferensi tiap elemen dalam hierarki. Jadi, model ini merupakan model pengambilan keputusan yang komprehensif. 


\section{B. Prinsip Dasar Pemikiran AHP}

Dalam menyelesaikan masalah dengan analisis logika eksplisit, sistem manajemen model ini akan membahas langkah-langkah yang digunakan dalam metode AHP (Analytical Hierarchy Process) dengan langkah-langkah sebagai berikut (Saaty, 2004):

Dekomposisi

Setelah pendefinisian masalah yang ada dapat dilakukan penguraian yaitu: mendeskripsikan unsur-unsu yang ada pada masalah tersebut. Ini dapat dilakukan hingga solusi ditemukan.

\section{Keputusan Komparatif (Keputusan Komparatif)}

Pada tingkat tertentu terdapat hubungan dengan tingkat di atasnya yang mana pedoman ini dapat menghasilkan penilaian terhadap dua elemen relatif. Hasil penilaian tersebut dapat ditampilkan dengan cara perbandingan berpasangan dan menghasilkan matriks (Perbandingan berpasangan).

\section{Penentuan Prioritas (Sintesis Prioritas)}

Setiap matriks perbandingan berpasangan dapat menghasilkan prioritas lokal. Karena setiap level memiliki matriks perbandingan berpasangan, sehingga dalam menentukan prioritas global dapat disintesiskan setiap prioritas lokal. Menurut hierarki persyaratan untuk melakukan sintesis tidak sama. Dalam berbagai permasalahan, cara menyikapi pendapat merupakan skala yang paling baik, yaitu skala 1 sampai dengan 9 .

Konsistensi Logis (Konsistensi Logis)

Konsistensi memiliki dua makna, yang pertama adalah peristiwa dan persamaan dapat disatukan dan menghasilkan objek yang sama. Kedua, kondisi tertentu yang memiliki tingkat dasar hubungan antar objek. Analisis ini diperlukan untuk mengetahui seberapa besar pengaruh atau pengaruh implementasi AHP dalam menjawab fenomena yang ada.

\section{METODE PENELITIAN}

Pengumpulan data dilakukan sesuai dengan kebutuhan penelitian AHP yang membutuhkan dua metode yang berbeda. Wawancara terstruktur digunakan untuk memperoleh informasi kualitatif, sedangkan kuesioner digunakan untuk memperoleh data kuantitatif (Creswell, 2013).

\section{a. Sebuah. Metode wawancara terstruktur}

Teknik wawancara melibatkan dialog langsung antara dosen, pengelola program studi dan mahasiswa. Informasi dikumpulkan dengan bantuan alat perekam, catatan, dan sebagainya, kemudian ditranskripsikan, dianalisis, dan diberi kode. Metode wawancara terstruktur adalah proses berorientasi tujuan yang sistematis. Struktur sistematis mengurangi masalah inheren interpretasi dan memungkinkan insinyur pengetahuan untuk mencegah distorsi yang disebabkan oleh subjektivitas orang yang diwawancarai.

\section{b. Daftar pertanyaan}

Untuk menemukan model AHP yang dapat diterapkan, semua entitas siswa menggunakan kuesioner berdasarkan pendekatan AHP dengan menggunakan matriks perbandingan pairwaise online (Saaty, 2008).

\section{c. Teknik Analisis Data}

Analisis kebutuhan menggunakan metode AHP untuk membantu perguruan tinggi memperoleh hasil yang lebih akurat. Perancangan ini meliputi 2 tahapan yaitu proses

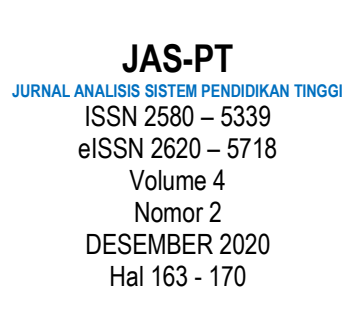

FORUM DOSEN INDONESIA 
menganalisis kebutuhan perangkat lunak dan merancang sistem pendukung keputusan dengan menggunakan metode AHP (Analytical Hierarchy Process).

Prinsip penyusunan hierarki adalah mendeskripsikan dan mendeskripsikan secara hierarkis, dengan memecah masalah menjadi elemen-elemen yang terpisah (Saaty, 2012). Anda melakukan ini dengan memecah pengetahuan, pemikiran kompleks kita menjadi bagian-bagiannya, kemudian bagian ini menjadi bagian-bagiannya, dan seterusnya secara hierarkis. Rincian tujuan hierarki yang lebih rendah terutama ditujukan untuk memperoleh kriteria yang dapat diukur. Padahal kenyataannya tidak selalu demikian. Dalam kasus tertentu, mungkin menguntungkan untuk menggunakan tujuan pada hierarki yang lebih tinggi dalam proses analisis. Semakin rendah deskripsi tujuan, semakin mudah menentukan ukuran objektif serta kriteria dan subkriteria. Namun, ada kalanya dalam proses analisis pengambilan keputusan tidak membutuhkan terlalu banyak detail. Sehingga salah satu cara untuk mengukur pencapaian tersebut adalah dengan menggunakan skala subyektif dan dianalisis menggunakan perangkat lunak pengolah AHP berupa Expert Choice versi 12.

\section{HASIL DAN PEMBAHASAN}

Universitas Sebelas Maret saat ini melaksanakan program reformasi birokrasi selama setahun sebagai dasar pembenahan dan peningkatan kualitas birokrasi dan kualitas pelayanan publik. Beberapa langkah reformasi birokrasi yang sedang dilakukan Universitas Maret meliputi delapan kategori berbeda seperti: 1) manajemen perubahan yang bertujuan untuk mendorong terciptanya budaya kerja positif yang kondusif bagi terciptanya birokrasi yang bersih dan akuntabel, efektif, dan efisien serta mampu memberikan pelayanan yang berkualitas, 2) memperkuat pengawasan yang bertujuan untuk mewujudkan birokrasi yang bersih dan bebas korupsi, kolusi dan nepotisme, 3) memperkuat akuntabilitas kinerja yang bertujuan mendorong birokrasi menjadi lebih berkinerja dan mampu mempertanggungjawabkan kinerjanya sesuai dengan semua sumber yang digunakannya, 4) memperkuat kelembagaan yang bertujuan untuk mendorong terciptanya lebih banyak budaya / perilaku yang kondusif untuk mewujudkan birokrasi yang efektif dan efisien.

Selanjutnya kategori berikut ini adalah: 5) penguatan aparatur yang bertujuan mendorong efisiensi penyelenggaraan pemerintahan dan pelayanan, serta merubah mentalitas aparatur, 6) memperkuat sistem manajemen sumber daya manusia yang bertujuan untuk memperoleh Sistem pengelolaan sumber daya manusia yang mampu menghasilkan tenaga kerja yang profesional, 7) memperkuat peraturan perundangundangan yang bertujuan untuk menciptakan sistem hukum yang lebih efektif dan menyentuh kebutuhan masyarakat, 8) meningkatkan kualitas pelayanan publik yang bertujuan untuk mendorong perubahan profesionalisme pelayanan penyedia dan meningkatkan kualitas layanan.

Berdasarkan determinan utama tersebut maka dikembangkan instrumen penelitian yaitu kuisioner berbasis AHP yang bertujuan untuk menyusun / menghasilkan kebijakan yang dapat dijadikan acuan untuk perbaikan kebijakan pada setiap focus group atau tujuan

JAS-PT

ISSN $2580-5339$ elSSN $2620-5718$ Volume 4 Nomor 2

DESEMBER 2020

Hal $163-170$

FORUM DOSEN INDONESIA organisasi. Dari poin ini, kami mengembangkan pendekatan sintetis untuk mengukur penerapan AHP seperti yang ditunjukkan pada gambar 1. Kriteria dan ukuran keberhasilan Reformasi Birokrasi memuat uraian atau penjabaran kriteria dan ukuran keberhasilan sebagaimana tertuang dalam Peraturan Presiden Nomor 81 Tahun 2010 tentang Grand Design Reformasi Birokrasi 2010-2025 dan Peraturan Menteri Pendayagunaan Aparatur Negara dan Reformasi Birokrasi. Republik Indonesia Nomor 11 Tahun 2015 tentang Road Map Reformasi Birokrasi 2015-2019. Uraian atau elaborasi 168 | JURNAL ANALISIS SISTEM PENDIDIKAN TINGGI | VOL. 4 NO. 2 2020, pp. 163-170 
terutama mengenai penjelasan masing-masing indikator keberhasilan dan cara pembuatannya.

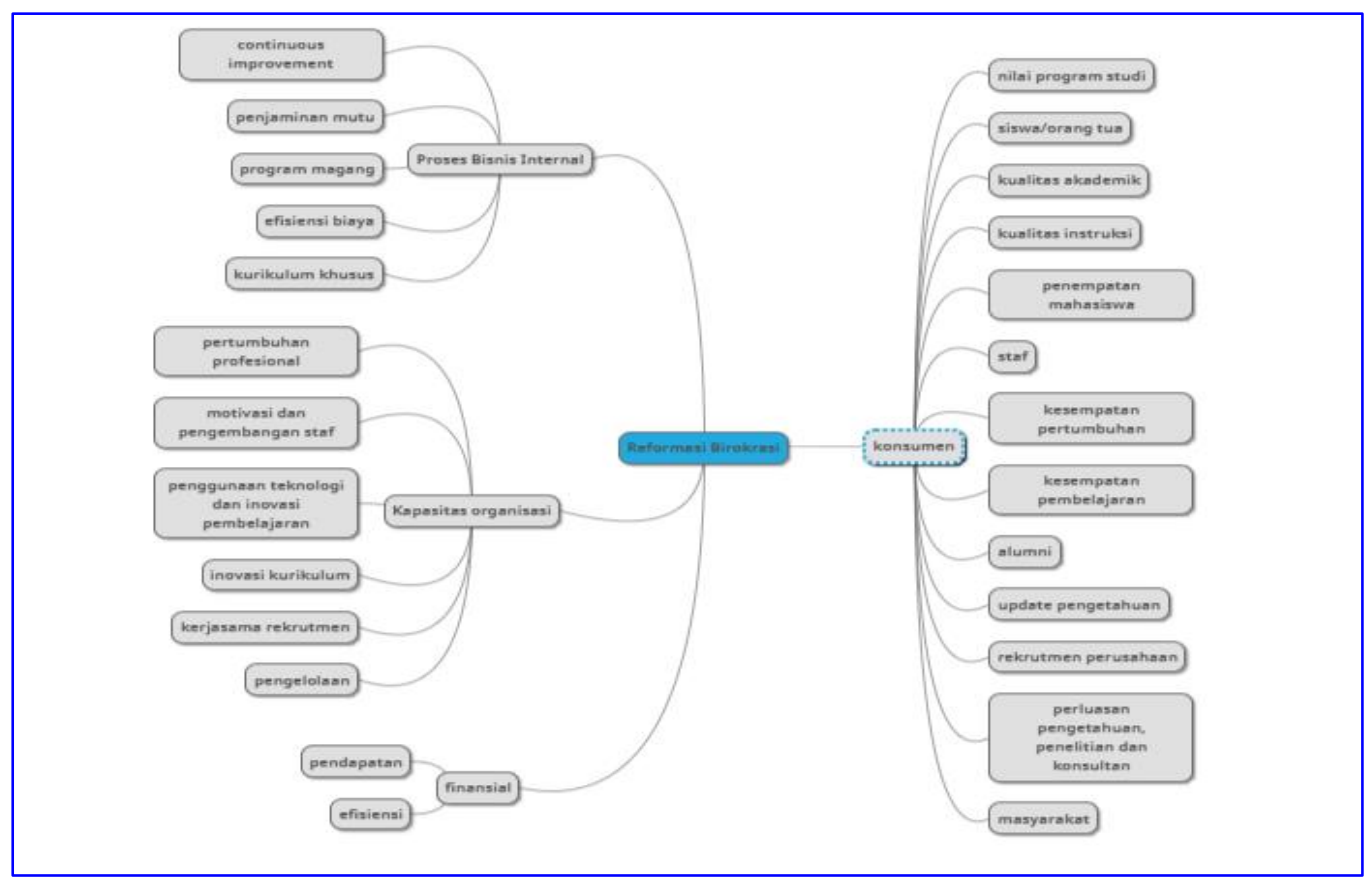

Gambar 1. Tampilan BSC - AHP

Kondisi tersebut di atas akan dicapai melalui berbagai upaya, termasuk pelaksanaan program quick win, yang merupakan langkah prakarsa yang mudah dan cepat untuk dicapai yang mengawali program besar dan sulit. Kemenangan cepat berguna untuk mendapatkan momentum awal yang positif dan meningkatkan kepercayaan badan untuk membuat perubahan yang sulit. Menyelesaikan sesuatu adalah inti dari program hebat apa pun. Kemenangan cepat dilakukan di awal dan dapat berupa kemenangan cepat untuk penataan organisasi, kepengurusan, peraturan perundang-undangan, sumber daya manusia aparatur, pengawasan, akuntabilitas, pelayanan publik, dan penataan budaya kerja organisasi.

\section{PENUTUP}

Penelitian ini menemukan bahwa empat perspektif Balanced Scorecard yang digunakan memiliki perbedaan bobot dan prioritas karena banyaknya perbedaan tingkat subkategorinya. Padahal tidak ada penilaian yang sempurna. BSC yang dikombinasikan dengan AHP saat ini, dapat digunakan untuk membuat metode penilaian terbaik yang mudah digunakan untuk menilai kinerja organisasi.

\section{DAFTAR PUSTAKA}

Andrews, M. (2015). "Explaining Positive Deviance in Public Sector Reforms in Development." World Development 74: 197-208.

Beverungen, A., C. Hoedemaekers dan J. Veldman (2014). "Charity and Finance in the University." Critical Perspectives on Accounting 25(1): 58-66.

Bureau for Development Policy (2011), United Nations Development Programme: Anticorruption Methods and Tools in Education Lo Res.One United Nations Plaza New York, NY 10017, USA

Bourgeois, R. 2005. Analytical Hierarchy Process: an Overview UNCAPSA - UNESCAP. Bogor

JAS-PT

JURNAL ANALISIS SISTEM PENDIDIKAN TINGGI

ISSN $2580-5339$ eISSN $2620-5718$

Volume 4

Nomor 2

DESEMBER 2020

Hal 163 - 170

FORUM DOSEN INDONESIA 
Christensen, C. M. dan H. J. Eyring (2011). The Innovative University: Changing the DNA of Higher Education from the inside Out, John Wiley \& Sons.

Corruption Perceptions Index 2019. Transparanacy Internasional. https://www.transparency.org/news/feature/corruption_perceptions_index_2019

Creswell, J. W. (2013). Research Design: Qualitative, Quantitative, and Mixed Methods Approaches, Sage publications.

Flamholtz, E. (1996). "Effective Organizational Control: A Framework, Applications, and Implications." European Management Journal 14(6): 596-611.

Indawati N ( 2015 ), The Development of Anti-Corruption Education Course for Primary School Teacher Education Students. Journal of Education and Practice, Vol.6, No.35, 2015.

Instruksi Presiden Republik Indonesia Nomor 5 Tahun 2004 tentang Percepatan Pemberantasan Korupsi

Instruksi Presiden Republik Indonesia Nomor 9 Tahun 2011 Tentang Rencana Aksi Pencegahan Dan Pemberantasan Korupsi

Instruksi Presiden Republik Indonesia Nomor 10 Tahun 2016 Tentang Rencana Aksi Pencegahan Dan Pemberantasan Korupsi.

Kaplan, S. Robert \& David P. Norton 2000. Balanced Scorecard: Menerapkan Strategi Menjadi Aksi. Jakarta (ID): Penerbit Erlangga

Kemendikbud. 2012. Pendidikan Anti Korupsi Untuk Perguruan Tinggi. Jakarta: Kementrian Pendidikan danKebudayaan Direktorat Perguruan Tinggi.

Lee, A.H., Chen, W.C., dan Chang, C.J., 2008. A Fuzzy AHP and BSC approach for evaluating performance of IT Department in the manufacturing industry in Taiwan. Expert Systems with Applications, 34, 96-107

Mahmudi, A. A., Surarso, B., \& Subagio, A. (2014). Kombinasi Balanced Scorecard dan Objective Matrix Untuk Penilaian Kinerja Perguruan Tinggi. JSINBIS (Jurnal Sistem Informasi Bisnis), 4(1), 01-10.

Mulyana, M. (2012). Consumer Behaviour: Sukses Dengan Memahami Konsumen.

Purnama, S \& Sundawa, D. (2017). The Development of Anti-corruption EducationModel toSupport Students Integrity Character in Schools through Civic Education(Case Study in Senior High School 8 Bandung). The Asian Conference on Education \& International Development 20170fficial Conference Proceedings. The International Academic Forum. www.iafor.org

Saaty, T. L., \& Vargas, L. G. (2012). Models, Methods, Concepts \& Applications of the Analytic Hierarchy Process. US: Springer.

Speer, J. (2012). "Participatory Governance Reform: A Good Strategy for Increasing Government Responsiveness and Improving Public Services?" World Development 40(12): 2379-2398.

Tjiptoherijanto, P. (2007). "Civil Service Reform in Indonesia." International Public Management Review 8(2): 31-44.

Turban, E., Aronson, J. E., and Linag, T. P. (2005). Decision Support Systems and Inteligent Systems

Undang-Undang Republik Indonesia Nomor 20 Tahun 2003 Tentang Sistem Pendidikan Nasional

JAS-PT

JURNAL ANALISIS SISTEM PENDIDIKAN TINGGI ISSN $2580-5339$ eISSN $2620-5718$

Volume 4

Nomor 2

DESEMBER 2020

Hal $163-170$

Wu, H.Y, Lin, Y.K., and Chang, C.H., 2011. Performance evaluation of extension education centers in universities base on the balanced scorecard. Journal Evaluation and Program Planning, 37-201.

Zakaria Zaherawati 2011. Key Performance Indicators (KPIs) in the Public Sector: A Study in Malaysia. Asian Social Science Vol. 7, No. 7; July 2011

FORUM DOSEN INDONESIA 